$$
\begin{aligned}
& \text { 震 }
\end{aligned}
$$

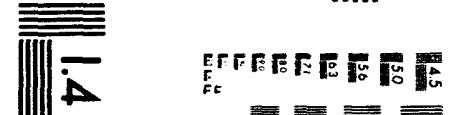

$$
\begin{aligned}
& \text { 更 }
\end{aligned}
$$

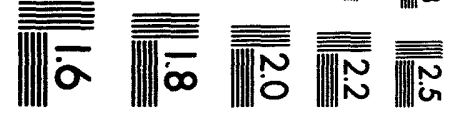




\section{ION EXCHANGE AT TNX USING THE SKID UNIT (U)}

by

M. L. Meyer

Westinghouse Savannah River Company

Savannah River Site

Aiken, South Carolina 29808

J. P. Bibler

$-4$

DOE Contract N. DE-AC09-89SR18035

This paper was prepared in connection with work done under the above contract number with the U.S.

Department of Energy. By acceptance of this paper, the publisher and/or recipient acknowledges the U. S. Government's right to retain a nonexclusive, royalty-free license in and to any copyright covering this paper, along with the right to reproduce and to authorize others to reproduce all or part of the copyrighted paper. 


\section{DISCLAIMER}

This report was prepared as an account of work sponsored by an agency of the United States Government. Neither the United States Government nor any agency thereof, nor any of their employees, makes any warranty, express or implied, or assumes any legal liability or responsibility for the accuracy, completeness, or usefulness of any information, apparatus, product, or process disclosed, or represents that its use would not infringe privately owned rights. Reference herein to any specific commercial product, process, or service by trade name, trademark, manufacturer, or otherwise does not necessarily constitute or imply its endorsement, recommendation, or favoring by the United States Government or any agency thereof. The views and opinions of authors expressed herein do not necessarily state or reflect those of the United States Government or any agency thereof.

This report has been reproduced directly from the best available copy.

Available to DOE and DOE contractors from the Office of Scientific and Technical Information, P. O. Box 62, Oak Ridge, TN 37831; prices available from (615) $576-8401$.

Available to the public from the National Technical Information Service, U. S. Department of Commerce, 5285 Port Royal Rd., Springfield, VA 22161 
WESTINGHOUSE SAVANNAH RIVER COMPANY

Savannah River Technology Center

WSRC-TR-93-564 Rev. 0

October 21, 1993

Keywords: Cesium Removal

Columns, Test

Facility, Radioactive

Wastes

TO:

W. L. TAMOSAITIS, 773-A

S.D. FINK, 773-A

CC: LWP File

N. N. TURNER, 679-T

D. K. SINGER, 679-T

D. A. BOYCE, 679-T

L. L. KILPATRICK, 676-T

TIM

FROM: J. P. BIBLER, 773-A GPß.
M. L. MEYER, 676-1T

ION EXCHANGE AT TNX USING THE SKID UNIT (U)

INTRODUCTION

An ion exchange unit has been manufactured for WSRC by British Nuclear Fuels, Ltd. This unit consists of three columns, ancillary valving, pumps, lines, anid computer controls. It has been delivered to TNX for use in testing a cesium-specific ion exchange resin, developed at WSRC as a potential second generation process for the decontamination of Defense Waste Processing Facility (DWPF) supernate. This resin also has Department of Energy (DOE) applications at both Oak Ridge and Hanford. Oak Ridge is interested in decontaminating the Melton Valley storage tank supernate, while Hanford is interested in decontaminating the 101-AW and 101-SY supernate streams. Another potential developmental interest is the Savannah River Site (SRS) DWPF recycle stream. The three primary waste streams of interest are the Oak Ridge, Hanford, and SRS, DWPF supernate streams. For these three waste streams, the cesium decontamination factor (DF) will be measured for a non-radioactive, simulated, high-level waste solution. The test objectives are as follows:

1. Investigate the resin hydraulic properties during water runs. This will include slurrying the resin in and out of the columns using process water. Particle size studies at the Savannah River Technology Center (SRTC) will characterize any resin physical degradation after transport to and from the column. Information needed from these tests, in addition to the resin friability on transport, includes the ability to transport the resin as a slurry and pressure drops across each column with the resin in place.

2. Test the resin cesium DF in a once-through mode using Oak Ridge Melton Valley Tank 25 simulant.

3. Test the resin cesium DF in a once-through mode using SRS supernate simulant.

4. Test the resin cesium DF in a once-through mode using Hanford 101-AW simulant. 
5. Test the resin cesium DF, elution with nitric acid, and resin half-life using Hanford 101AW simulant. This will require repeated feed-elute cycles to determine how many cycles can be performed before the resin must be replaced.

6. Test the column performance in a once-through mode with Hanford 101-AW simulant containing $200 \mathrm{ppm}$ simulated sludge solids. This will provide data to indicate whether prefiltration is necessary for ion exchange if solids are present in the supernate.

7. Test the column with a simulated DWPF recycle waste stream. This will provide cesium DF data for the resin. Additional prefiltration studies will be required, since the stream is known to contain significant quantities of solids.

\section{PROCESS DESCRIPTION \& DESIGN BASIS}

The SKID, as its' name implies, is a skid-mounted ion exchange unit used to demonstrate cesium removal using a SRS developed resorcinol-formaldehyde (RF) resin. The resin material diameter ranges from 20-50 mesh with an absolute density, bulk density in caustic, and bulk density in water of $1.4,0.36$ and $0.5 \mathrm{~g} / \mathrm{ml}$ respectively. Bench-scale tests indicate 200 column volumes of waste feed can be processed for every volume of resin material. This resin is hygroscopic and retains 26 weight percent in moisture.

The SKID facility consists of two primary areas: the feed/chemical and supply/receipt tanks, and the ion exchange columns. The feed/chemical and supply/receipt tanks provide storage for caustic $(\mathrm{NaOH})$, acid $\left(\mathrm{HNO}_{3}\right)$, simulated feed, spent acid and washwater solutions. A preliminary sketch of the supply tank area is shown Figure 1.

The SKID has three identical ion exchange columns (V1001, V1002, V1003). The column design is based on a throughput of 10 bed volumes/hour so that the equipment is kept to a reasonable size. The SKID maximum operating temperature is $35^{\circ} \mathrm{C}$. The operating capacity is $754 \mathrm{gal} / \mathrm{hr}(\approx 12.6 \mathrm{gal} / \mathrm{min})$, but has a maximum flow capacity of $2642 \mathrm{gal} / \mathrm{hr}(\approx 44 \mathrm{gal} / \mathrm{min})$ for transferring the resin slurry in and out of the unit. Each ion exchange column has an empty volume of $219 \mathrm{gal}$, and a void volume of $142 \mathrm{gal}$ when the resin is in place.

At any one time, two columns will be on-line, with the simulant being fed in series. The third column will be off-line from the process, being prepared for use in the ion-exchange sequence. The three columns are operated in a carousel configuration as summarized in Table 1. The SKID unit can operate in two different modes the once-through and the regenerative mode.

Table 1. SKID Unit Carousel Configuration

\begin{tabular}{|l|c|c|c|}
\hline & V1001 & V1002 & V1003 \\
\hline \hline Position 1 & lead & lag & offline \\
\hline Position 2 & offline & lead & lag \\
\hline Position 3 & lag & offline & lead \\
\hline
\end{tabular}




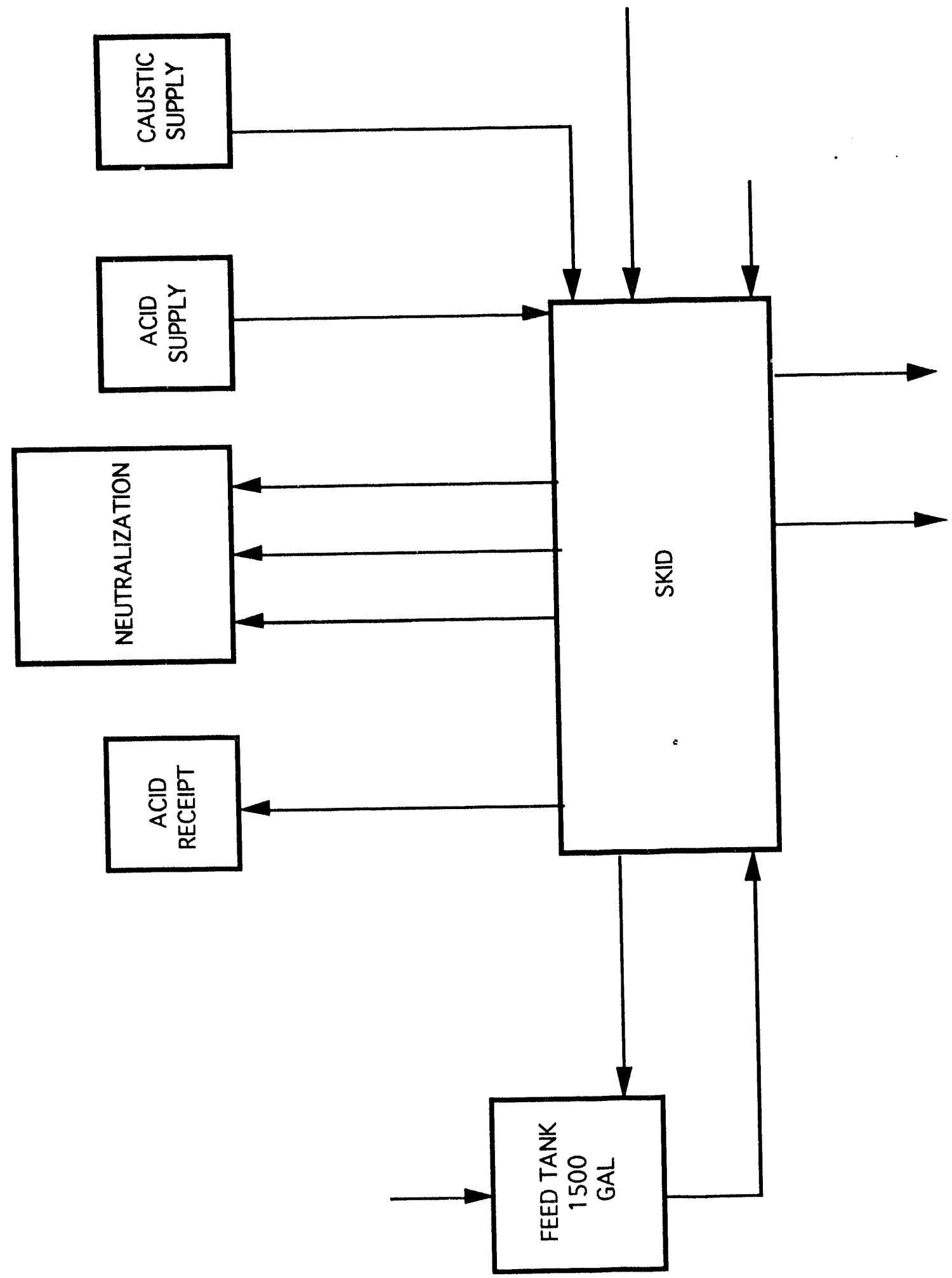

Figure 1. Process Flowsheet 


\section{Once-Through Mode}

In the once-through mode the resin batch is only used a single time until it reaches a desired breakthrough or becomes spent. A typical operating sequence is as follows:

1. Fill the empty column with water, and slurry a water/resin mixture into the column.

2. Wash the resin with process water in the backflow mode to redistribute the resin and send the wash water to drain.

3. Condition the resin using caustic in the downflow mode. Drain the caustic into a neutralization holding tank.

4. Supply simulated waste feed to the ion exchange columns in the downflow mode until the desired breakthrough is attained on the lead column. Send any simulated residual waste feed to the feed supply tank.

5. Wash the resin with caustic.

6. Wash the resin with water in the downflow mode.

7. Wash the resin a second time with water in the downflow mode.

8. Wash the resin with acid to elute the collected ion off the column.

9. Wash the resin with water in the downflow mode.

10. Transfer the resin out of the column, collecting the resin material in a filtration device.

11. Drain and rinse the ion exchange columns with a small volume of water. Transfer any residual resin out of the ion exchange columns.

\section{Regenerative Mode}

In the regenerative mode, a sequence of operations are carried out to chemically treat the resin so that it can be re-used in the ion exchange process. The initial steps for the regenerative mode are the same as those mentioned in steps 1-6 for the once-through mode. To regenerate the column, the following additional operational sequence is completed:

1. The spent resin is eluted with acid in the upflow mode to remove any cesium ions from the resin. This also converts the resin back into the hydrogen form.

2. Water wash the resin column in the upflow mode displacing the acid to a separate receipt tank and water wash to a neutralization holding tank.

3. Condition the resin using caustic in the downflow mode. Drain the caustic into a neutralization holding tank.

\section{TEST OBJECTIVES}

\section{Once-Through Operating Mode Using Chemical Simulants}

Once-through testing on the waste simulants will involve processing a simulated supernate through two resin beds in series until $50 \%$ cesium breakthrough is obtained on the lead column (See Figure 2). 


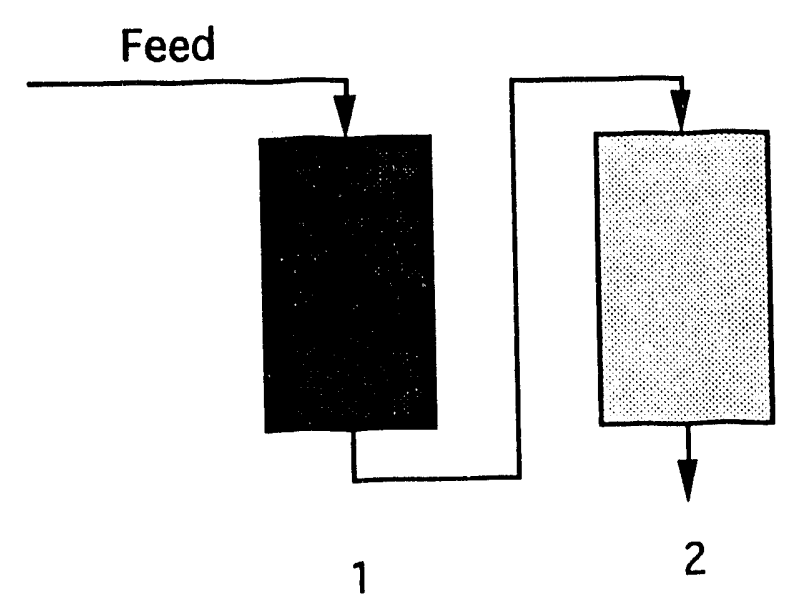

\section{Feed}

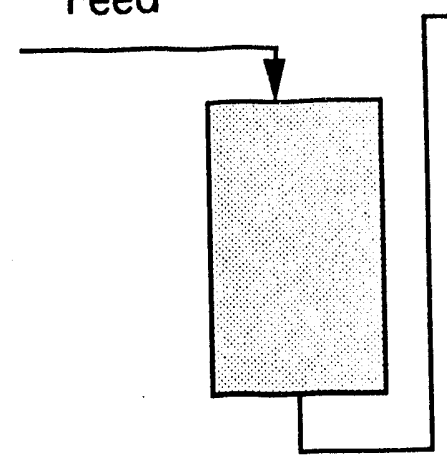

2

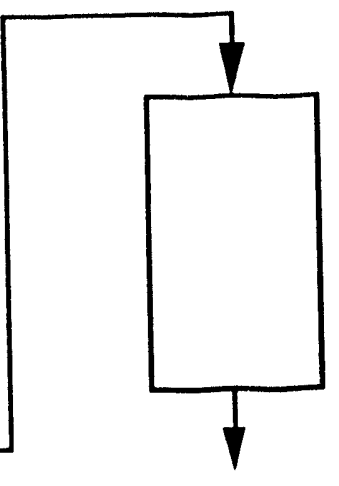

3

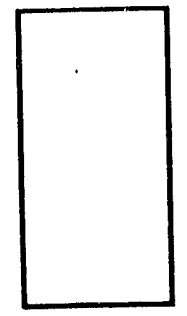

3

Elutriant

represents clean column

represents partially spent column

represents spent column

Figure 2. Carousel Operation of Three Ion Exchange Columns

When breakthrough is attained, both columns will be washed with caustic. Following a water wash, both columns will also be eluted with an appropriate volume of $0.5 \mathrm{M} \mathrm{HNO}_{3}$ and the eluate analyzed to determine the concentration of sodium, potassium, and cesium ions. Both columns will be washed with water and reconditioned with $\mathrm{NaOH}$ prior to any treatment of a new supernate simulant.

During chemical runs, three supernate streams and a supernate stream with sludge solids added are planned for testing. The three supernate simulants are based on the Oak Ridge Melton Valley Tank 25 Waste, the Savannah River Site High-Level Waste, and the Hanford 101-AW Waste stream. The first supernate simulant to be tested will be the Melton Valley Tank 25 composition from Oak Ridge. Although it contains the same major components as the SRS and Hanford supernates, it is the most dilute of the three streams. Table 2 gives the compositon of Oak Ridge, SRS, and Hanford simulants that will be used in the once-through tests. Once the Oak Ridge test is complete, the simulant will be removed from the system for disposal. The SRS feed stream 
will be used for both the SRS and Hanford testing. This will be accomplished by adjusting the feed composition by chemical addition to the SRS simulant. The feed solutions will require continuous agitation to ensure feed uniformity.

Table 2. Chemical Composition of Supernate Simulants

\begin{tabular}{|c|c|c|c|c|c|c|}
\hline \multirow[b]{2}{*}{ Chemical } & \multicolumn{2}{|c|}{ Qak Ridge } & \multicolumn{2}{|c|}{ Savannah River } & \multicolumn{2}{|c|}{ Hanford 101-AW } \\
\hline & g/Liter & Molarity & g/liter & Molarity & g/Liter & Molarity \\
\hline $\mathrm{NaOH}$ & 2.4 & 0.061 & 116 & 2.9 & 280 & 7.1 \\
\hline $\mathrm{Al}\left(\mathrm{NO}_{3}\right)_{3} .9 \mathrm{H}_{2} \mathrm{O}$ & 0.060 & $1.6 \mathrm{E}-4$ & 143 & 0.38 & 190 & 0.50 \\
\hline $\mathrm{NaNO}_{3}$ & 220 & 2.6 & 101 & 1.2 & 200 & 2.4 \\
\hline $\mathrm{NaNO}_{2}$ & --- & ----- & 49 & 0.71 & 75.9 & 1.1 \\
\hline $\mathrm{Na}_{2} \mathrm{CO}_{3} \cdot \mathrm{H}_{2} \mathrm{O}$ & 1.24 & 0.01 & 25 & 0.20 & 27 & 0.21 \\
\hline $\mathrm{Na}_{2} \mathrm{SO}_{4}$ & 7.4 & 0.052 & 24 & 0.17 & 1.4 & 0.01 \\
\hline $\mathrm{KNO}_{3}$ & 43 & 0.43 & 1.5 & 0.012 & 111 & 1.1 \\
\hline $\mathrm{CsNO}_{3}$ & $2.6 \mathrm{E}-6$ & $1.3 \mathrm{E}-8$ & 0.049 & $2.4 \mathrm{E}-4$ & 0.028 & $1.4 \mathrm{E}-4$ \\
\hline TOTA & {$\left[\mathrm{Na}^{+}\right]$} & 3.6 & & 5.6 & & 11 \\
\hline
\end{tabular}

Oak Ridge Simulant Test

The influent and effluent volumes and destinations for the once-through test using the Oak Ridge simulated supernate are given in Table 3. Because of the required feed volume, available tankage, and the simulant preparation cost, the feed will be recycled. Since the RF resin will only remove cesium, the feed can be recycled to the feed tank. The cesium concentration will be maintained at a constant level by metering a $\mathrm{CsNO}_{3}$ solution into the feed tank. Each time a new resin bed is used, the resin will be slurried into the column with a minimum of $3 \mathrm{~m}^{3}$ (793 gal) of process water. It will also be treated with $2.85 \mathrm{~m}^{3}$ (378 gal) of $2 \mathrm{M} \mathrm{NaOH}$ for two reasons: 1 ) to convert the resin to the sodium form 2) to make the bed caustic. If the bed is not maintained at a high $\mathrm{pH}$, the aluminum in the feed will precipitate as it meets the resin aqueous interface. This would decrease the ion exchange efficiency, and cause a significant column pressure drop.

To minimize waste volume, simulated supernate will be used to push any residual $2 \mathrm{M} \mathrm{NaOH}$ off the resin column to the neutralization tank. Feeding of the simulated supernate will continue until $50 \%$ cesium ion breakthrough on the lead column is obtained. To remove the cesium ion when the feed cycle has been completed for the lead column, the resin in both columns is treated again with $2 \mathrm{M} \mathrm{NaOH}$. The volume of interstitial feed solution that is displaced by the caustic treatment will be returned to the neutralization tank. The caustic treatment is followed by a water wash generating a slightly caustic liquid destined for the neutralization tank. Elution of the cesium ion from the resin is accomplished using $0.5 \mathrm{M} \mathrm{HNO}_{3}$, and is sent to the acid receipt tank. The operating sequence and wastewater generation rate is shown in Table 3. A process flow diagram for the various streams is shown in Attachment 1. 
Table 3. Once-Through Component Volumes Using Oak Ridge Simulant on Two Columns in Series

\begin{tabular}{|c|c|c|c|}
\hline Process Step & Component & Cycle Volume & Destination \\
\hline Float off fines & $\begin{array}{l}\text { Process water } \\
\text { Resin fines }\end{array}$ & $\begin{array}{l}300 \text { gallons } \\
13 \text { gallons* }\end{array}$ & $\begin{array}{c}\text { Drain } \\
\text { Bag filter/Clean waste }\end{array}$ \\
\hline Slurry resin into columns & $\begin{array}{l}\text { Process water } \\
\text { Resin }\end{array}$ & $\begin{array}{l}1,424 \text { gallons } \\
160 \text { gallons }\end{array}$ & $\begin{array}{l}\text { Process drain } \\
\text { Next test }\end{array}$ \\
\hline Condition with $2 \mathrm{M} \mathrm{NaOH}$ & $2 \mathrm{M} \mathrm{NaOH}$ & 756 gallons & Neutralization tank \\
\hline Feed simulant & $\begin{array}{l}\text { OR simulant } \\
\text { (See Table 2) }\end{array}$ & 1,500 gallons & Disposal ETP/ETF \\
\hline Feed simulant (interstitial) & OR simulant & 3 gallons & Neutralization tank \\
\hline Add $\mathrm{Cs}^{+}$to feed & $\mathrm{CsNO}_{3}$ & 1 gallon & Feed tank \\
\hline Caustic wash & $2 \mathrm{M} \mathrm{NaOH}$ & 756 gallons & Neutralization tank \\
\hline Water wash & Process water & 756 gallons & Neutralization tank \\
\hline Elution & $0.5 \mathrm{M} \mathrm{HNO}_{3}$ & 1600 gallons & Disposal ETP/ETF \\
\hline Water wash & Process water & 756 gallons & Neutralization tank \\
\hline
\end{tabular}

Another perspective for this test, relative to the influents and effluents and their destinations follows:

Influents for two columns:

- Ion exchange resin: 160 gallons

- Filtered process water : $1,424(1,584-160)$ gallons used for slurrying in resin 1,512 gallons for washing resin 300 gallons for fines removal

- $2 \mathrm{M} \mathrm{NaOH}: 2,268$ gallons from caustic tank

- Feed: 1,500 gallons simulated Oak Ridge supernate

- 0.5 M HNO3: 1600 gallons

\section{Effluents from two columns:}

- Neutral process water: 1,424 gallons to process drain

- Caustic process water: 1512 gallons to neutralization tank

- Acidic process water: 756 gallons to neutralization tank 
- $2 \mathrm{M} \mathrm{NaOH}: 1,512$ gallons to neutralization tank [The hydrcxide concentration in the neutralization tank will be approximately $1 \mathrm{M}$ and will have to be neutralized prior to disposal due to constraints of process sewer.]

- Feed simulant: 3 gallons to neutralization tank to be mixed with 3024 gallons of $1 \mathrm{M}$ $\mathrm{NaOH}$ for a total volume of 3027 gallons. [Cs ${ }^{+}$concentration will be $1.6 \mathrm{E}-6 \mathrm{mg} / \mathrm{l}$ in the neutralization tank.] The original 1500 gallon feed solution will be sent to the H-Area ETF for disposal.

- Filter used to capture fines: one to solid waste

- Filter cartridge on process water inlet stream: unknown number - to solid waste

- Acid eluate: $0.5 \mathrm{M} \mathrm{HNO}_{3}$ containing $9.5 \mathrm{E}-4 \mathrm{mg} / \mathrm{C}{ }^{+}-1600$ gallons to be neutralized and disposed at the ETP or ETF.

Recycled Substances

Treated simulant feed will be recycled to the simulant feed tank. Cesium nitrate will be metered into the recycle stream to replenish the $\mathrm{Cs}^{+}$. This stream, 1,500 gallons maximum, will be disposed by sending it to the ETP/ETF.

\section{Savannah River Simulant Test}

Although reconstituting the Oak Ridge simulant with additional chemicals would generate less waste, the sodium and potassium nitrate concentrations for the Savannah River simulant is less than the Oak Ridge simulant concentration. The Savannah River simulant can only be produced by making a fresh simulant. The Savannah River simulant will be processed in the same manner as the Oak Ridge simulant, and Table 4 describes the solution volumes needed/generated during the test. A process flow diagram for the various streams is shown in Attachment 1 . The resin from the previous test will be reused after being treated with $2 \mathrm{M} \mathrm{NaOH}$.

Table 4. Once-Through Component Volumes Using Savánnah River Simulant on Two Columns in Series

\begin{tabular}{|c|c|c|c|}
\hline Process Step & Component & Cycle Volume & Destination \\
\hline Condition with $2 \mathrm{M} \mathrm{NaOH}$ & $2 \mathrm{M} \mathrm{NaOH}$ & 756 gallons & Neutralization tank \\
\hline Feed simulant & $\begin{array}{l}\text { SRS simulant } \\
\text { (See Table 2) }\end{array}$ & $\begin{array}{l}1,500 \text { gallons } \\
\text { reused }\end{array}$ & $\begin{array}{l}\text { Feed tank; reconstitute } \\
\text { for next test series }\end{array}$ \\
\hline Feed simulant (interstitial) & SRS simulant & 3 gallons & Neutralization tank \\
\hline Add $\mathrm{Cs}^{+}$to feed & $\mathrm{CsNO}_{3}$ & 1 gallon & Feed tank \\
\hline Caustic wash & $2 \mathrm{M} \mathrm{NaOH}$ & 756 gallons & Neutralization tank \\
\hline Water wash & Process water & 756 gallons & Neutralization tank \\
\hline Elution & $0.5 \mathrm{M} \mathrm{HNO}_{3}$ & 1600 gallons & ETP/ETF \\
\hline Water wash & Process water & 756 gallons & Neutralization tank \\
\hline Slurry resin out & $\begin{array}{l}\text { Process water } \\
\text { Resin }\end{array}$ & $\begin{array}{l}6,124 \text { gallons } \\
160 \text { gallons }\end{array}$ & $\begin{array}{c}\text { Drain } \\
\text { Bag filter }\end{array}$ \\
\hline
\end{tabular}


The various influent and effluent destinations are described in the following text:

\section{Influents:}

- Filtered process water : 6,124 gallons used for slurrying in resin out of columns

- $2 \mathrm{M} \mathrm{NaOH}: 756$ gallons from caustic tank

1,512 gallons for washing resin

- Feed: 1,500 gallons simulated Savannah River supernate

- 0.5 M HNO3: 1600 gallons

\section{Effluents:}

- Neutral process water: 6,124 gallons to process drain

- Caustic process water: 756 gallons to neutralization tank

- Acidic process water: 756 gallons to neutralization tank

- $2 \mathrm{M} \mathrm{NaOH}$ : 1,512 gallons to neutralization tank [The hydroxide concentration in the neutralization tank will be approximately $1 \mathrm{M}$ and will have to be neutralized prior to disposal due to process sewer constraints.]

- Feed simulant: 3 gallons to neutralization tank to be mixed with 3,024 gallons of $1 \mathrm{M}$ $\mathrm{NaOH}$ for a total volume of 3027 gallons. [ $\mathrm{Cs}^{+}$concentration will be $0.03 \mathrm{mg} / \mathrm{l}$ in the neutralization tank.]

- Filter used to capture fines: one to solid waste

- Filter cartridge on process water inlet stream: unknown number - to solid waste

- Acid eluate: $0.5 \mathrm{M} \mathrm{HNO}_{3}$ containing $319 \mathrm{mg} / \mathrm{l} \mathrm{Cs}{ }^{+}$- 1600 gallons to be neutralized and disposed of at ETP/ETF

\section{Recycled Substances}

Treated simulant feed will be recycled to the feed tank. Cesiam nitrate will be metered into the recycle stream to replenish the $\mathrm{Cs}^{+}$that is removed by the ion exchange columns. This stream, 1,500 gallons maximum, will be saved and chemicals will be added to make the composition equivalent to that of the Hanford 10!-AW simulant.

The resin will be removed from the columns and new resin introduced for the Hanford simulant because extended operating runs are planned in the elution mode to determine the resin operating life.

\section{Hanford 101-AW Simulant Tests Once-Through \& Elution Mode of Operation}

\section{Once Through}

Tests using the Hanford 101-AW simulant are primarily directed at determining the resin operating life. The resin operating life is defined as the number of feed/elute cycles that can be completed before the resin must be replaced. Data generated in the first cycle will be equivalent to a once-through mode test. After satisfying the once-through test conditions, the columns will be operated in successive elution cycles until it is determined that $20 \%$ of the resin capacity has been lost. When this reduced resin capacity is observed, the test will be terminated.

The following chemicals will be added to the feed tank to convert the remaining Savannah River simulant to Hanford 101-AW simulant:

- $164 \mathrm{~g} \mathrm{NaOH} /$ liter (this will probably be added as $\sim 50 \% \mathrm{NaOH}$ solution and will require enough solution to add a total of $953 \mathrm{~kg}$ of $\mathrm{NaOH}$ ) 
- $254 \mathrm{~kg}$ of $\mathrm{Al}\left(\mathrm{NO}_{3}\right)_{3} \cdot 9 \mathrm{H}_{2} \mathrm{O}$

- $153 \mathrm{~kg}$ of $\mathrm{NaNO}_{2}$

- $7.3 \mathrm{~kg}$ of $\mathrm{Na}_{2} \mathrm{CO}_{3} \cdot \mathrm{H}_{2} \mathrm{O}$

- $160 \mathrm{~g} \mathrm{CsNO} 3$

- $561 \mathrm{~kg} \mathrm{NaNO} 3$

- Process water will be added to bring the total volume to about 1,500 gallons (5.7 $\mathrm{E}+3$ liters).

The simulant will be sampled and analyzed prior to system testing to verify the feed components concentration.

\section{Elution Mode}

For this series of tests, all three SKID columns unit will be utilized. They will be operated in a carousel fashion as described in Table 1. Table 5 outlines the process steps and solution volumes needed for the first once-through test. Table 6 notes the process steps for continual column elution after saturation with cesium ion. Table 7 lists the process steps for the last elution cycle, which includes slurrying the resin out of the ion exchange columns. The process flow diagrams for each scenario are shown in Attachment 1.

Table 5. Once-Through (First Cycle) Component Volumes Using Hanford 101-AW Simulant on Two Columns in Series

\begin{tabular}{|c|c|c|c|}
\hline Process Step & Component & Cycle Volume & Destination \\
\hline Float off fines & $\begin{array}{l}\text { Process water } \\
\text { Resin fines }\end{array}$ & $\begin{array}{l}1,000 \text { gallons } \\
19 \text { gallons* }\end{array}$ & $\begin{array}{c}\text { Drain } \\
\text { Bag filter/Clean waste }\end{array}$ \\
\hline Slurry resin into columns & $\begin{array}{l}\text { Process water } \\
\text { Resin }\end{array}$ & $\begin{array}{l}2,028 \text { gallons } \\
240 \text { gallons }\end{array}$ & $\begin{array}{l}\text { Process drain } \\
\text { Next test }\end{array}$ \\
\hline $\begin{array}{l}\text { Condition with } 6 \mathrm{M} \mathrm{NaOH} \\
\text { (Columns } 1 \& 2 \text { ) }\end{array}$ & $6 \mathrm{M} \mathrm{NaOH}$ & 756 gallons & Neutralization tank \\
\hline Feed simulant & $\begin{array}{l}\text { 101-AW } \\
\text { (See Table 3) }\end{array}$ & $\begin{array}{l}1,500 \text { gallons } \\
\text { reused }\end{array}$ & $\begin{array}{l}\text { Feed tank; reconstitute } \\
\text { for next test series }\end{array}$ \\
\hline Feed simulant (interstitial) & $101-\mathrm{AW}$ & 3 gallons & Neutralization tank \\
\hline Add $\mathrm{Cs}^{+}$to feed & $\mathrm{CsNO}_{3}$ & 1 gallon & Feed tank \\
\hline Caustic wash & $6 \mathrm{M} \mathrm{NaOH}$ & 756 gallons & Neutralization tank \\
\hline Water wash & Process water & 756 gallons & Neutralization tank \\
\hline Elution & $0.5 \mathrm{M} \mathrm{HNO}_{3}$ & 1600 gallons & ETP/ETF \\
\hline Water wash & Process water & 756 gallons & Neutralization tank \\
\hline
\end{tabular}

*-estimated as $8 \%$ of the total resin volume feed 
Influent and effluent volumes for this test are shown below.

Influents:

- Ion exchange resin: 240 gallons

- Filtered process water : $2028(2,268-240)$ gallons used for slurrying in resin $1, \ldots 12$ gallons for washing resin 1,000 gallons for fines removal

- $6 \mathrm{M} \mathrm{NaOH}: 1,512$ gallons from caustic tank

- Feed: 1,500 gallons simulated Hanford 101-AW supernate

- $0.5 \mathrm{M} \mathrm{HNO} 3$ : 1600 gallons

\section{Effluents:}

- Neutral process water: 2,028 gallons to process drain

- Caustic process water: 756 gallons to neutralization tank

- Acidic process water: 756 gallons to neutralization tank

- $6 \mathrm{M} \mathrm{NaOH}$ : 1,512 gallons to neutralization tank [The hydroxide concentration in the neutralization tank will be approximately $3.0 \mathrm{M}$ and will have to be neutralized prior to disposal.]

- Feed simulant: 3 gallons to neutralization tank to be mixed with 3,024 gallons of $3 \mathrm{M}$ $\mathrm{NaOH}$ for a total volume of 3027 gallons. [Cs ${ }^{+}$concentration will be $0.013 \mathrm{mg} / \mathrm{l}$ in the neutralization tank.]

- Filter used to capture fines: one to solid waste

- Filter cartridge on process water inlet stream: unknown number - to solid waste

- Acid eluate: $0.5 \mathrm{M} \mathrm{HNO}_{3}$ containing $372 \mathrm{mg} / \mathrm{C} \mathrm{Cs}^{+}-1600$ gallons to be neutralized and sent to F/H ETF or to a vendor for disposal

Table 6. Volumes Generated From a Single Column for Carousel Operation Using the Hanford 101-A W Simulant

\section{Process Step}

Condition with $6 \mathrm{M} \mathrm{NaOH}$

(Columns 1, 2 \&3)

Feed simulant

Feed simulant (interstitial)

Add $\mathrm{Cs}^{+}$to feed

Caustic wash

(Column 1)

Water wash

(Column 1)

Elution

(Column 1)

Water wash
Component

$6 \mathrm{M} \mathrm{NaOH}$

101-AW

(See Table 2)

101-AW

$\mathrm{CsNO}_{3}$

$6 \mathrm{M} \mathrm{NaOH}$

Process water

378 gallons

Neutralization tank

$0.5 \mathrm{M} \mathrm{HNO}_{3} 1600$ gallons

Process water 378 gallons

Destination

Neutralization tank

Feed tank; reconstitute for next test series

Neutralization tank

Feed tank

Neutralization tank

378 gallons

ETP/ETF

Neutralization tank 
The caustic, water wash and acid elution will be repeated for columns 2 and 3. A minimum of six cycles is estimated for each position (e. g. 1, 2, 3). The total waste volume generation is therefore, six times the operating volumes mentioned in Table 7. The influents, effluents and their destinations on a per cycle basis is as follows:

\section{Influents.}

- Filtered process water : 1,512 gallons for washing resin

- $6 \mathrm{M} \mathrm{NaOH}$ : 1134 gallons for preconditioning, 378 gallons for caustic washes

- Feed: 1,500 gallons simulated Hanford 101-AW supernate

- 0.5 M HNO3: 1600 gallons

\section{Effluents:}

- Caustic process water: 378 gallons to neutralization tank

- Acidic process water: 378 gallons to neutralization tank

- $6 \mathrm{M} \mathrm{NaOH}: 1,134$ gallons for preconditioning, 378 gallons for caustic washes to neutralization tank [The hydroxide concentration in the neutralization tank will be $3 \mathrm{M}$ during each caustic and water wash cycle assuming neutralization to $\mathrm{pH} 7$ prior to disposal. Adjustment of the $\mathrm{pH}$ is required due to process sewer constraints.]

- Feed simulant: 3 gallons to neutralization tank to be mixed with 2,268 gallons of $3 \mathrm{M}$ $\mathrm{NaOH}$ for a total volume of 2,271 gallons. [Cs ${ }^{+}$concentration will be $0.0168 \mathrm{mg} / \mathrm{l}$ in the neutralization tank prior to final $\mathrm{pH}$ adjustment]

- Filter cartridge on process water inlet stream: unknown number - to solid waste

- Acid eluate: $0.5 \mathrm{M} \mathrm{HNO}_{3}$ containing $372 \mathrm{mg} / \mathrm{l} \mathrm{Cs}{ }^{+}-1600$ gallons to be neutralized and disposed at the ETP/ETF

It is understood that a certain amount of simulated supernate will have to be added to the feed tank to replenish supernate lost to the neutralization tank and due to sampling. The final operating cycle with the Hanford 101-AW simulant containing cesium ion will follow the outline in Table 7. The only difference in the final elution cycle mentioned in Table 8 compared to the volumes in Table 6 is the ion exchange resin removal.

Table 7. Final Elution Cycle Volumes Using Hanford 101-AW Simulant

\begin{tabular}{|c|c|c|c|}
\hline Process Step & Component & Cycle Volume & Destination \\
\hline Condition with $6 \mathrm{M} \mathrm{NaOH}$ & $6 \mathrm{M} \mathrm{NaOH}$ & 378 gallons & Neutralization tank \\
\hline Feed simulant & $\begin{array}{l}\text { 101-AW } \\
\text { (See Table3) }\end{array}$ & $\begin{array}{l}1,500 \text { gallons } \\
\text { reused }\end{array}$ & $\begin{array}{l}\text { Feed tank; reconstitute } \\
\text { for next test series }\end{array}$ \\
\hline Feed simulant (interstitial) & 101-AW & 3 gallons & Neutralization tank \\
\hline Add $\mathrm{Cs}^{+}$to feed & $\mathrm{CsNO}_{3}$ & 1 gallon & Feed tank \\
\hline Caustic wash & $6 \mathrm{M} \mathrm{NaOH}$ & 378 gallons & Neutralization tank \\
\hline Water wash & Process water & 378 gallons & Neutralization tank \\
\hline Elution & $0.5 \mathrm{M} \mathrm{HNO}_{3}$ & 1600 gallons & ETP/ETF \\
\hline Water wash & Process water & 378 gallons & Neutralization tank \\
\hline
\end{tabular}


Slurry resin out

$\begin{array}{lr}\text { Process water } & 9,186 \text { gallons } \\ \text { Resin } & 240 \text { gallons }\end{array}$

Drain

Bag filter

The influents, effluents and their destinations is as follows:

Influents:

- Filtered process water : 9,186 gallons used for slurrying in resin out of columns

756 gallons for washing resin

- $6 \mathrm{M} \mathrm{NaOH}: 378$ gallons from caustic tank

- Feed: 1,500 gallons simulated Hanford 101-AW supernate

- $0.5 \mathrm{M} \mathrm{HNO} 3$ : 1600 gallons

\section{Effluents:}

- Neutral process water: 9,186 gallons to process drain

- Caustic process water: 378 gallons to neutralization tank

- Acidic process water: 378 gallons to neutralization tank

- $6 \mathrm{M} \mathrm{NaOH}$ : 756 gallons to neutralization tank [The hydroxide concentration in the neutralization tank will be approximately $3 \mathrm{M}$ and will have to be neutralized prior to disposal due to process sewer constraints.]

- Feed simulant: 3 gallons to neutralization tank to be mixed with 1512 gallons of $3 \mathrm{M}$ $\mathrm{NaOH}$ for a total volume of 1515 gallons. [Cs ${ }^{+}$concentration will be $0.0275 \mathrm{mg} / \mathrm{l}$ in the neutralization tank.]

- Filter used to capture fines: one to solid waste

- Filter cartridge on process water inlet stream: unknown number - to solid waste

- Acid eluate: $0.5 \mathrm{M} \mathrm{HNO}_{3}$ containing $372 \mathrm{mg} / 1 \mathrm{Cs}^{+}-1600$ gallons to be neutralized and disposed of at ETP/ETF

- Ion exchange resin: 240 gallons to bag filter for ultimate disposal as solid waste

The feed simulant will be retained for use in the sludge solids test.

\section{Once-Through Operation With SRS Sludge Solids}

Pumping actual supernate from a waste tank into an ion exchange pretreatment system is expected to incorporate small amounts of sludge particles suspended in the supernate. The major components in the sludge are presented in Table 8 . It is expected that sludge accumulation on the resin bed top will cause a high pressure drop across the column. To determine how sludge solids suspension affects the ion exchange process, a test will be conducted using 200 parts per million suspended solids. A single column of fresh resin will be used for the test. Supernate containing the sludge solids will be processed through the column until 24,000 gallons of feed has been treated, or until the column pressure drop limits are exceeded. Since the test objective is only to identify the effect of sludge addition, cesium addition will not be made during this run. The process steps and material volumes are given in Table 10. A process flow diagram for the various streams is shown in Attachment 1. 
Table 8. Major Components of SRS Simulated Sludge (Based on Dried Sludge)

Element

$\mathrm{Fe}$
$\mathrm{Si}$
$\mathrm{Mn}$
$\mathrm{B}$
$\mathrm{Mg}$
$\mathrm{Na}$
$\mathrm{Al}$
$\mathrm{Ca}$
$\mathrm{Li}$
$\mathrm{Zn}$

\section{Weight \%}

12.1

5.1

2.8

0.64

0.30

7.1

3.5

1.7

0.53

0.20

Table 9. Component Volumes Using Hanford 101-AW Simulant Containing 200 ppm SRS Sludge Solids on One Column

\begin{tabular}{|c|c|c|c|}
\hline Process Step & Component & Cycle Volume & Destination \\
\hline Float off fines & $\begin{array}{l}\text { Process water } \\
\text { Resin fines }\end{array}$ & $\begin{array}{l}300 \text { gallons } \\
6.4 \text { gallons* }\end{array}$ & $\begin{array}{c}\text { Drain } \\
\text { Bagfilter/Clean waste }\end{array}$ \\
\hline Slurry resin into columns & $\begin{array}{l}\text { Process water } \\
\text { Resin }\end{array}$ & $\begin{array}{l}712 \text { gallons } \\
80 \text { gallons }\end{array}$ & $\begin{array}{l}\text { Process drain } \\
\text { Solid waste }\end{array}$ \\
\hline Condition with $6 \mathrm{M} \mathrm{NaOH}$ & $6 \mathrm{M} \mathrm{NaOH}$ & 378 gallons & Neutralization tank \\
\hline Feed simulant & $\begin{array}{l}\text { 101-AW } \\
+ \text { solids }\end{array}$ & 1,500 gallons & Disposal at ETP/ETF \\
\hline Feed simulant (interstitial) & 101-AW & 3 gallons & Neutralization tank \\
\hline Add solids to feed & $\begin{array}{l}\text { Solids } \\
\text { concentrate }\end{array}$ & 1 gallon & Feed tank \\
\hline Caustic wash & $6 \mathrm{M} \mathrm{NaOH}$ & 378 gallons & Neutralization tank \\
\hline Water wash & Process water & 378 gallons & Neutralization tank \\
\hline Slurry resin out & $\begin{array}{l}\text { Process water } \\
\text { Resin }\end{array}$ & $\begin{array}{l}3,062 \text { gallons } \\
80 \text { gallons }\end{array}$ & $\begin{array}{l}\text { Drain } \\
\text { Bag filter; solid waste }\end{array}$ \\
\hline \multicolumn{4}{|c|}{$\begin{array}{l}\text { Influents: } \\
\begin{aligned}- & \text { Ion exchange resin: } 80 \text { gallons } \\
\text { Filtered process water : } & 712 \text { (792 - 80) gallons used for slurrying in resin } \\
& 3,062 \text { gallons for slurrying out resin } \\
& 378 \text { gallons for washing resin } \\
& 300 \text { gallons for fines removal }\end{aligned} \\
-6 \mathrm{M} \mathrm{NaOH:} 756 \text { gallons from caustic tank }\end{array}$} \\
\hline
\end{tabular}


- Feed: 1,500 gallons simulated Hanford 101-AW simulant rlus solids (no $\mathrm{Cs}^{+}$)

\section{Effluents from two columns:}

- Neutral process water: 3,062 gallons to process drain

- Caustic process water: 378 gallons to neutralization tank

- $6 \mathrm{M} \mathrm{NaOH}$ : 756 gallons to neutralization tank [The hydroxide concentration in the neutralization tank will be approximately $4 \mathrm{M}$ and will have to be neutralized prior to disposal due to process sewer constraints.]

- Feed simulant: 3 gallons to neutralization tank to be mixed with 1,134 gallons of $4 \mathrm{M} \mathrm{NaOH}$ for a total volume of 1,137 gallons.

- Filter used to capture fines: one to solid waste

- Filter cartridge on process water inlet stream: - to solid waste

- Feed simulant: 1,500 gallons: Disposal at ETP/ETF

- Resin: 80 gallons to bag filter for reuse or disposal to solid waste

\section{DWPF Recycle Tests}

The scope of these tests is not currently defined in the same detail as the previously discussed testing. Since the composition, particle content and dissolved solids for the DWPF recycle stream is currently indeterminate, a test plan cannot be specified. Once the chemical and physical nature of the feed stream have been defined, the tests will be performed as deemed appropriate. Additional prefiltration studies are also anticipated to process this waste stream using ion exchange.

\section{QUALITY ASSURANCE}

The bases and calculations for the nitrate and cesium ion concentrations presented in this document are contained in WSRC-92-339 and maintained by Michael L. Meyer. 


\section{ATTACHMENT 1}




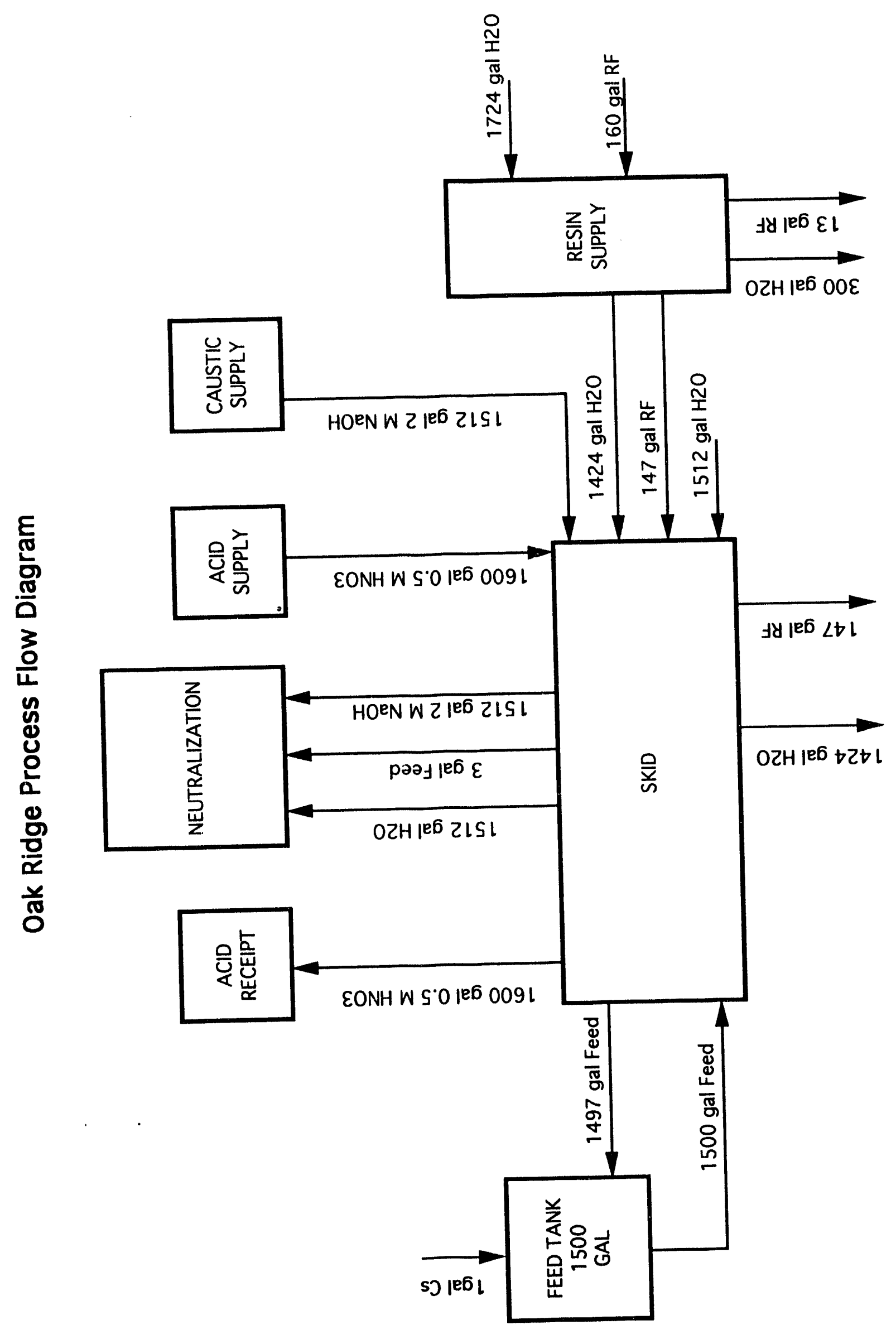




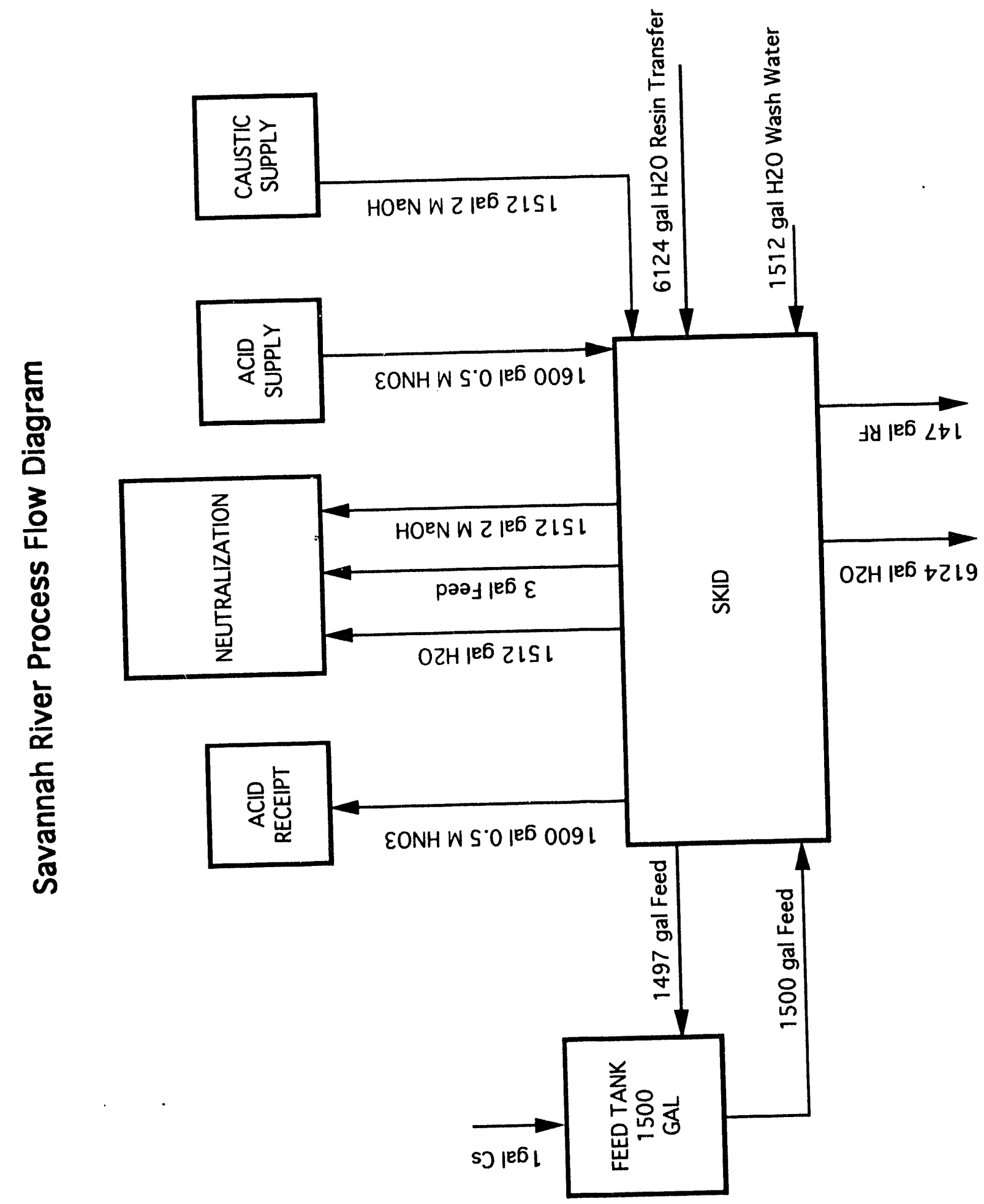




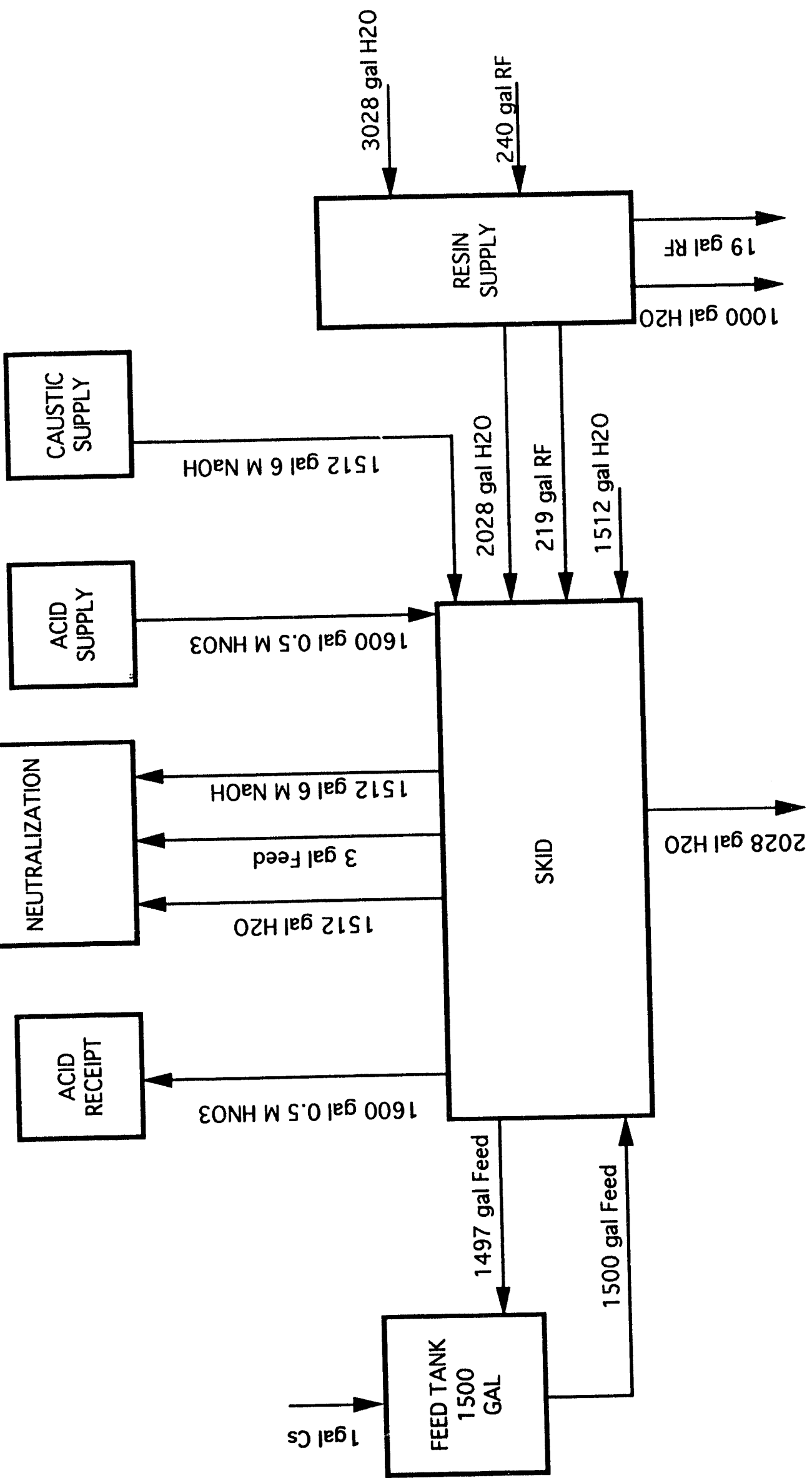




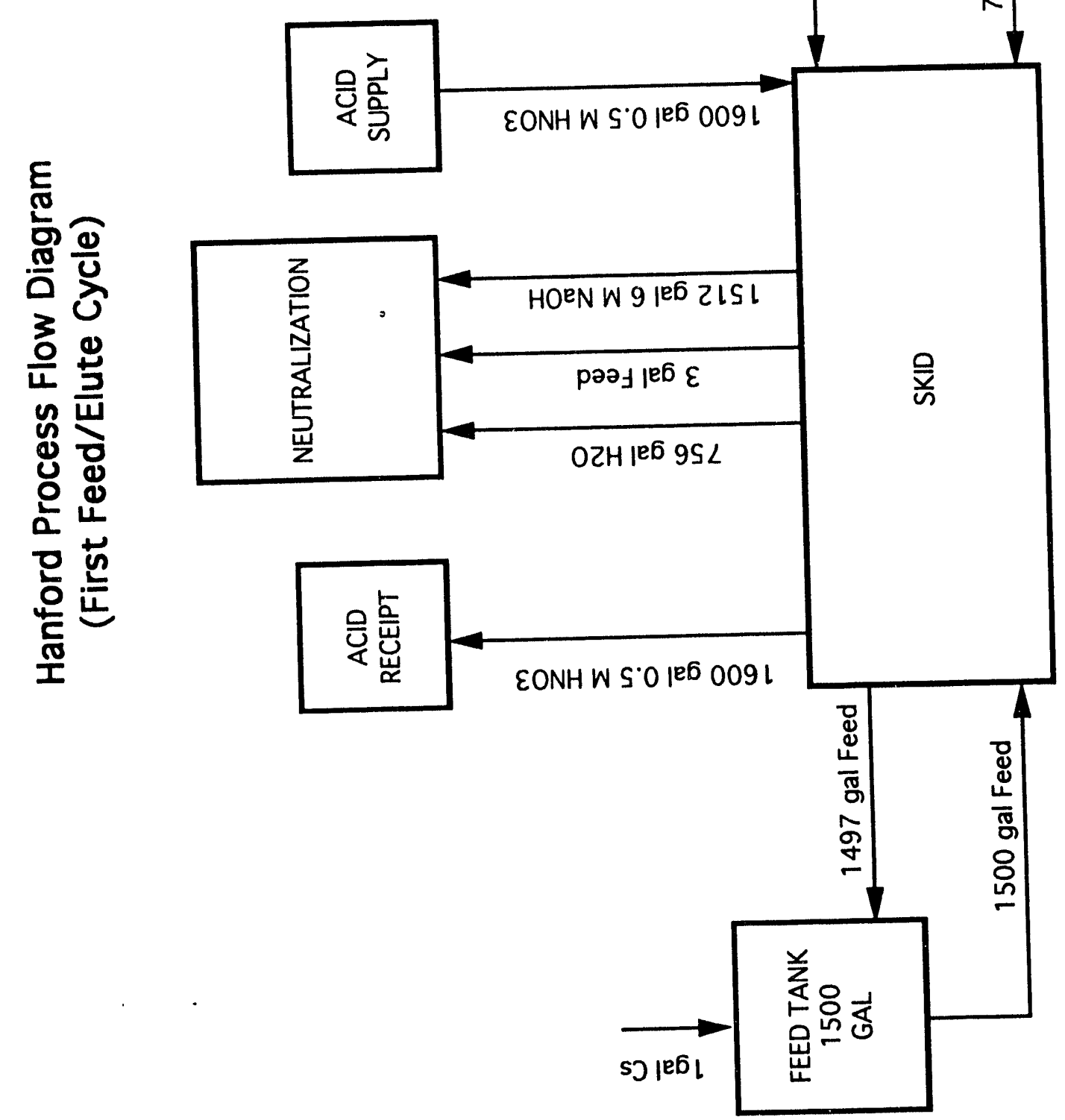

$$
\text { 警 }
$$

HOEN W 9 IEE ZISL 


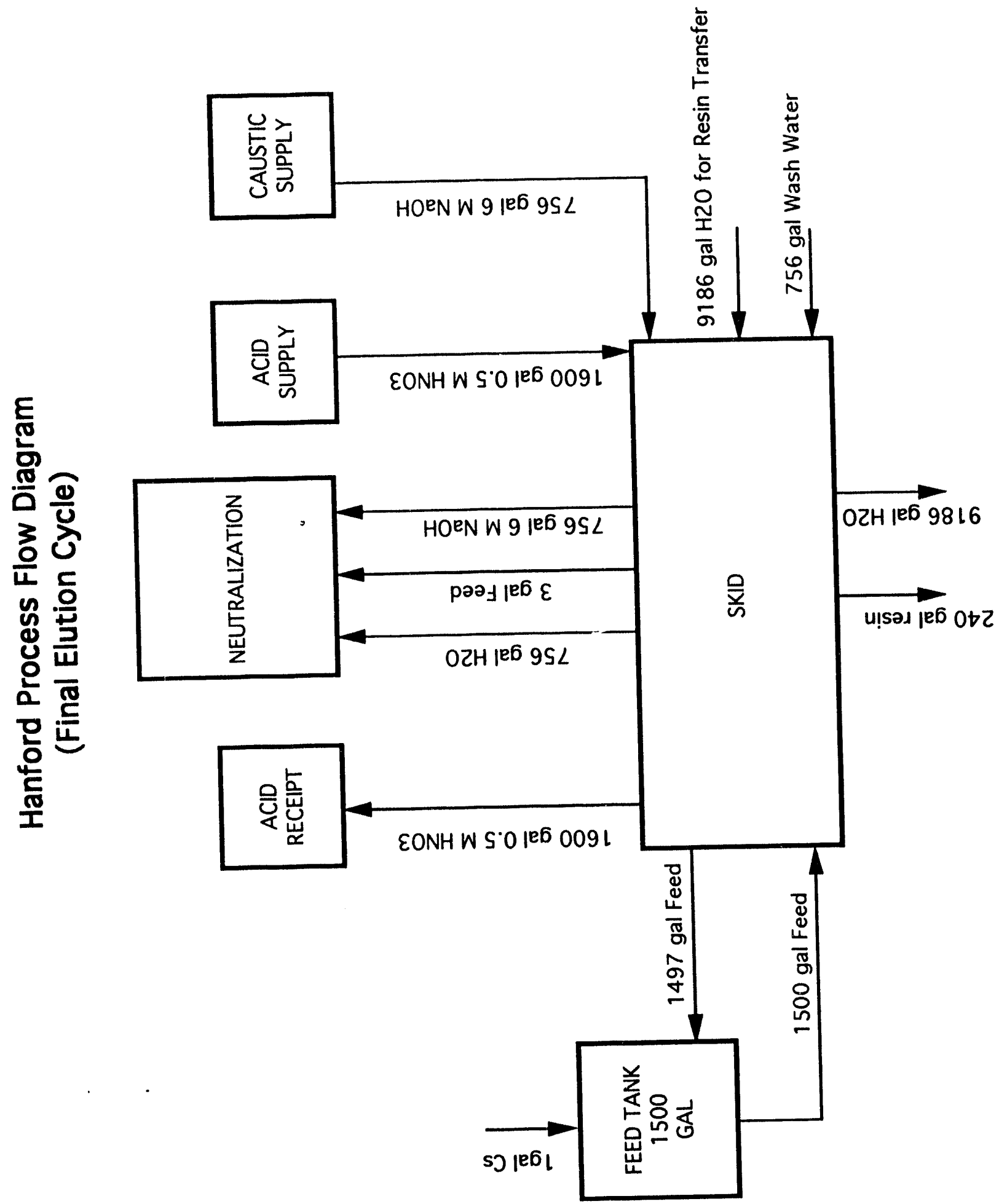




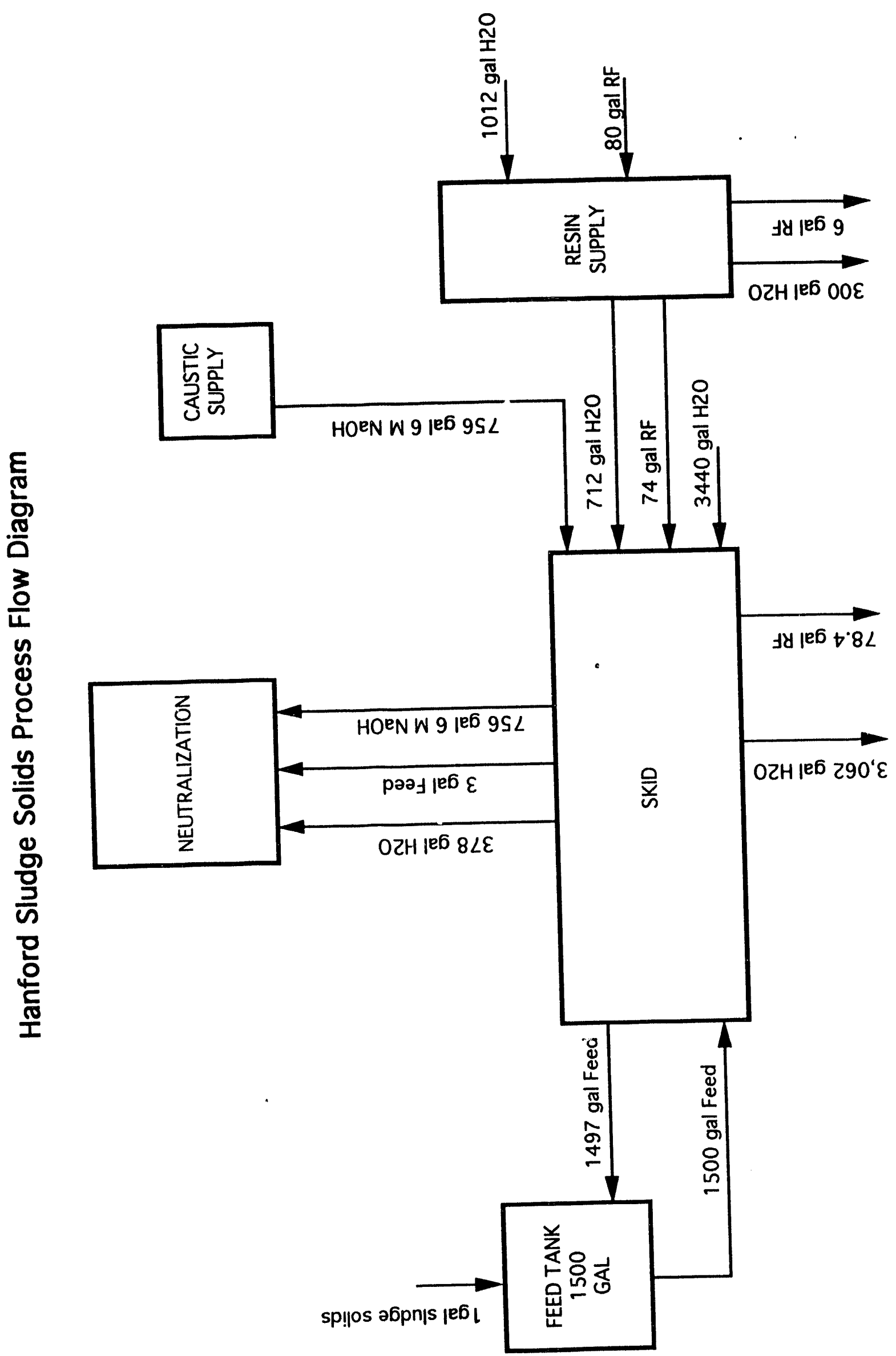



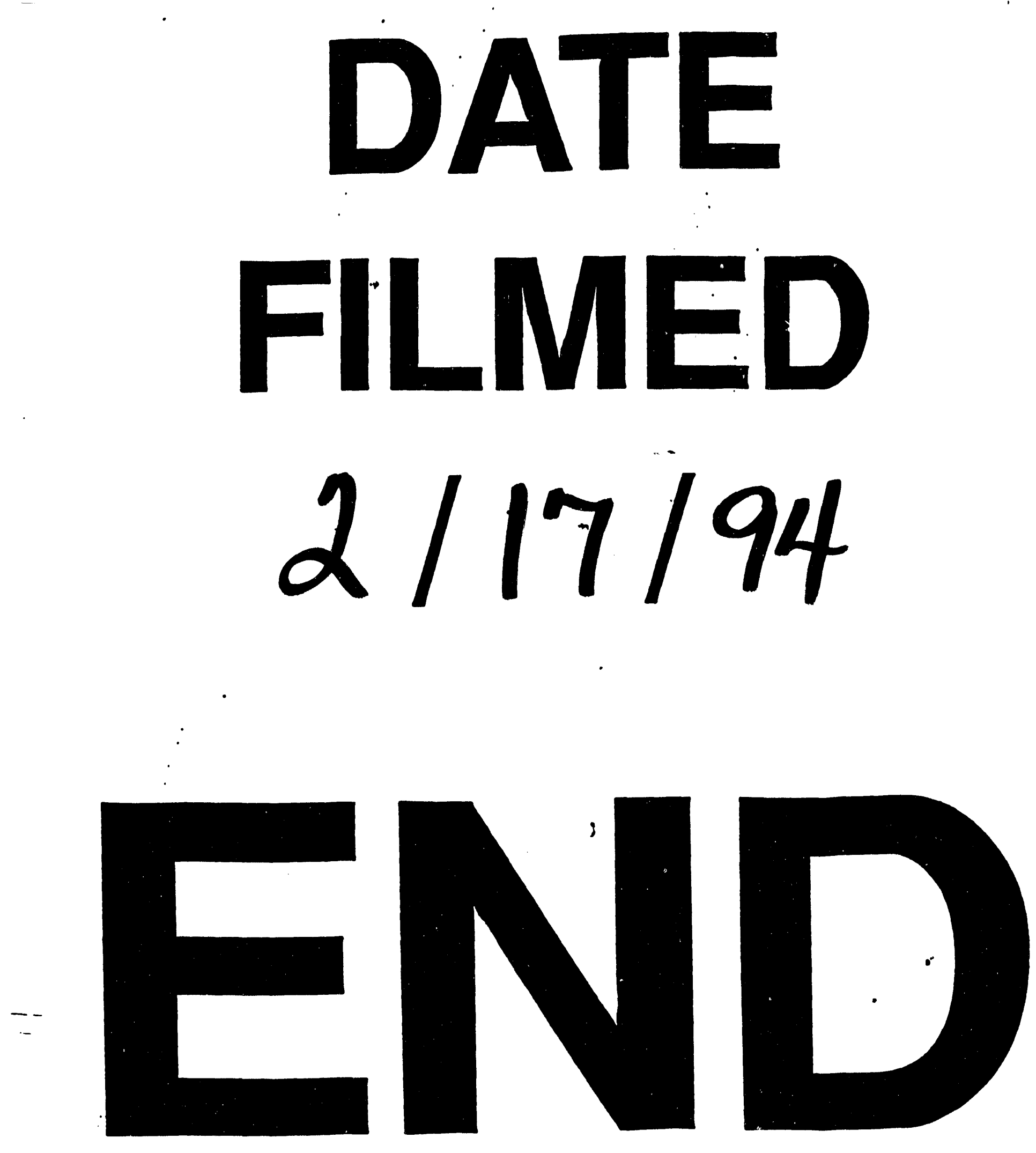